\title{
Silver Economy and the Development Policy of Rural Areas in Poland
}

\author{
Grażyna KRZYMINIEWSKA, Hanna PONDEL \\ Poznań University of Economics and Business, Poznań, Poland \\ \{grazyna.krzyminiewska, hanna.pondel\}@ue.poznan.pl
}

\begin{abstract}
This article is an attempt to assess to what extent silver economy may become a development driver of rural areas. In the first part of the paper, attention focused on the scale of population ageing in rural areas and assumptions of silver economy. Hereinafter in the article, selected national strategic documents and programmes are presented and assessed in terms of their usefulness for the implementation of the silver economy concept in rural areas. Thus, the aim of the paper is to present and assess the place of various areas of silver economy activity in the development policy of Polish rural areas to which the descriptive statistics method was applied. The analysis performed shows that currently in Poland progress has been achieved in operationalisation of activities in the area of silver economy at quite a general level - programmes addressed to seniors as the overall community are created. On the other hand, roadmaps are missing for the implementation of senior policy for specific segments of elderly populations inhabiting rural areas where unfavourable demographic situation is particularly visible and where the society ageing process proceeds at a much slower space than across the country.
\end{abstract}

Keywords: Silver Economy, Society Ageing, Rural Areas.

\section{$1 \quad$ Introduction}

For years, the ageing society has been perceived as a social problem related mainly to the growing amount of disbursed social benefits and the necessity to develop the health care system and care services. However, the approach to this problem has been changing over the years - obviously, it is different in various countries and depends, for example on the level of their social and economic development, the level of welfare and activity of the society, including the elderly. Within a given country it is also possible to observe diversification of the elderly population - in terms of age, occupation, education, activity and place of residence. More and more attention is paid to the problems of silver economy associated with the elderly population, however, it is still a subject which is not recognised, requiring many studies and adopting specific development scenarios.

This article is an attempt to assess to what extent silver economy may become a development driver of rural areas. It is an issue extremely interesting due to the 
changing image of the Polish village in terms of social and occupational structure - a decreasing percentage of persons earning their living in agriculture and the evolution of functions fulfilled by rural areas.

\section{The Aim and Research Methodology}

The aim of the paper is to present and assess the place of various areas of silver economy activity in the development policy of Polish rural areas. In order to accomplish this objective, national strategic documents and programmes were selected and assessed in terms of their usefulness for the implementation of the silver economy. The base for the selection of documents and programs was primarily the area of regulation and support and the recipients of specific activities. Taking into account these criteria, Development Programme of Rural Areas for the years 2014-2020 and National Regional Development Strategy 2010-2020. Regions, cities, rural areas, as well as a pilot Programme Active and Healthy Senior Farmer and Multi annual Programme "Senior+" for the years 2015-2020 were considered as particularly important for rural areas. The analyzed documents have a different time horizon, hence their analysis should be treated as a "case study", not a comparative analysis. The time range of research is determined by the date of the introduction and functioning of programs and strategies, however mainly it presents the period of the last few years.

Studying the subject, a critical review of the literature was carried out and the descriptive statistics method was applied. Secondary sources were used to achieve the goal: literature of the subject, national and EU documents and programs, materials made available by public institutions, legal acts.

\section{Development of Silver Economy in the Context of Ageing Processes}

In the nearest decades, the Polish society will have to face challenges related to the phenomenon of population ageing. Demographic forecasts clearly indicate the growth of share of the elderly and in accordance with the GUS data, the share of persons aged 65 and more in the total population of Poland in 2050 will reach $30.2 \%$. In the same year, persons aged 80 and more will make $10.4 \%$ of the total population (in $2013-$ $3.9 \%$ ) [3]. Population ageing will refer to all communities and a significant growth of the elderly (with a certain decline in the years 2030-2035) will also affect rural areas (Figure 1). Due to the current weakness of the social and technical infrastructure supporting the elderly in rural areas, it triggers a significant risk of increased inequalities.

In accordance with the forecast, a $16.8 \mathrm{pp}$ growth in the percentage of the elderly $(+65)$ in the village is expected and, at the same time, the share of the elderly in the forecast period will exceed $30 \%$ of the overall population in rural areas.

The scale of the population ageing processes raises understandable concern associated with the current inefficiency of care systems and inefficiency of the social 
security system [10]. On the other hand, a different view of the population ageing phenomenon appears, the view through the perspective of new development opportunities compliant with the silver economy concept, where attention is paid to the fact that such processes may become a reason of the "new development path", without ignoring the risks of the ageing process for the economic growth.

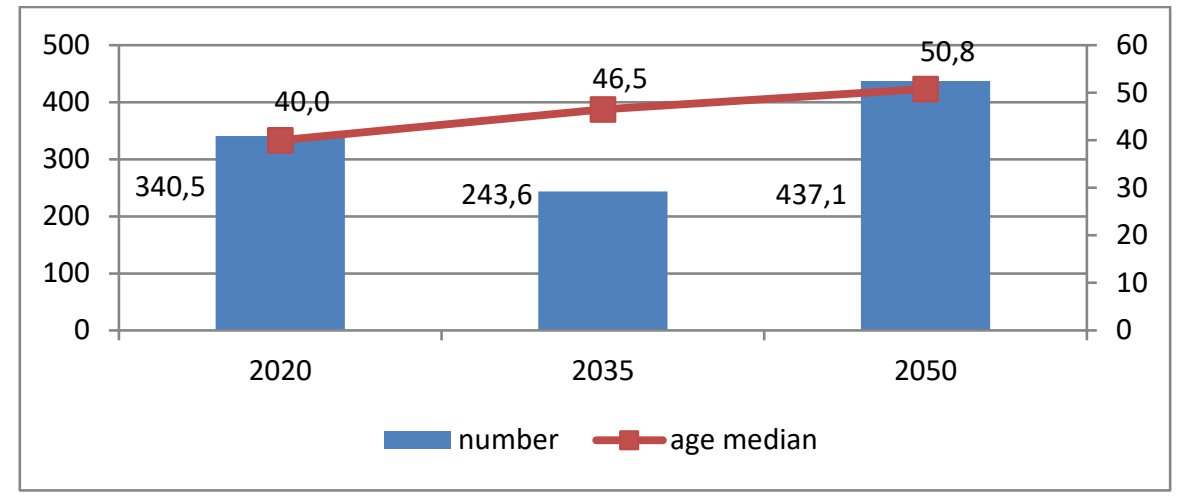

Fig. 1. Number of rural population $65+$ (in thousand) and age median of village population in the years 2020-2050 [3].

In the OECD document [18] The Silver Economy as a Pathway for Growth experts explicitly state that "Several efforts are underway to drive a paradigm shift that views the ageing as assets not liabilities".

The silver economy concept means the economic system oriented towards the adjustment of manufacturing, distribution of goods and services areas to the needs of the ageing population. The silver economy concept appeared in the European Union documents as early as at the beginning of the twentieth century, when attention was place on the fact that ageing of the European population may create an opportunity to increase the competitiveness of the European economy through the production of goods and services addressed to the elderly [5] as well as that the development of innovative enterprises will also enable to expand the development capacity based on global markets since the population ageing problem is becoming characteristic for many nonEuropean countries [4]. In accordance with this approach, the European Commission defines silver economy as the existing and emerging economic opportunities arising from the growing public and consumer expenditure related to population ageing and the specific needs of the population over 50 [8].

On the other hand, the OECD recognises silver economy as silver production, i.e. the economy which produces and delivers products and services targeted at the elderly, developing the environment in which people over 60 cooperate and are successful at work, engage in innovative projects, assist in market development as consumers and lead a healthy, active and productive life [18].

In the Polish literature of the subject, Golinowska [9] uses a very accurate definition of silver economy which indicates that silver economy involves targeting of supply adequately to changing needs of various groups of the elderly, so that they become a 
source of economic activation. Regardless the adopted method of silver economy definition, we always deal with representatives of economy undertaking supply activities addressed to the elderly who become beneficiaries in this process. The essence of silver economy is not only the positive impact on the quality of life of the elderly. It also means a positive effect on the labour market, allowing for friendly treatment of older employees, better understanding seniors' needs and problems as well as triggering of the creative sector and growth of employment in sectors using the latest technologies. Enste, Naegele and Leve [7] classify, among others, the following industries as those where silver economy may stimulate the development of market branches directly and indirectly associated with population ageing:

- information technology (IT) in healthcare,

- adapting dwellings and life facilitating services based primarily on IT,

- independent life based on growing use of IT,

- gerontology areas significant for health economics, including medical technologies and e-health, supporting hearing and sight, prosthetics and orthopaedics,

- education and culture as a response to the willingness to develop and manage free time,

- IT and media linked with medicine, promoting independence and security,

- robotics of services connected with the promotion of independent life in case of elderly persons suffering from severe diseases,

- mobility and promoting its elements, e.g. traffic safety,

- leisure, travel, culture, communication and entertainment,

- fitness and wellness as a response to trigger the awareness of a healthy lifestyle;

- clothing and fashion as a symptom of strive for social integration,

- services facilitating daily operations and other household works,

- insurance referring mainly to risk forms typical for the elderly,

- financial services, in particular in the area of capital protection, wealth preservation and prevention of savings loss.

Taking into account the diversified (but containing common elements) way of silver economy understanding, its holistic dimension may be adopted, as indicated in Figure 2. 


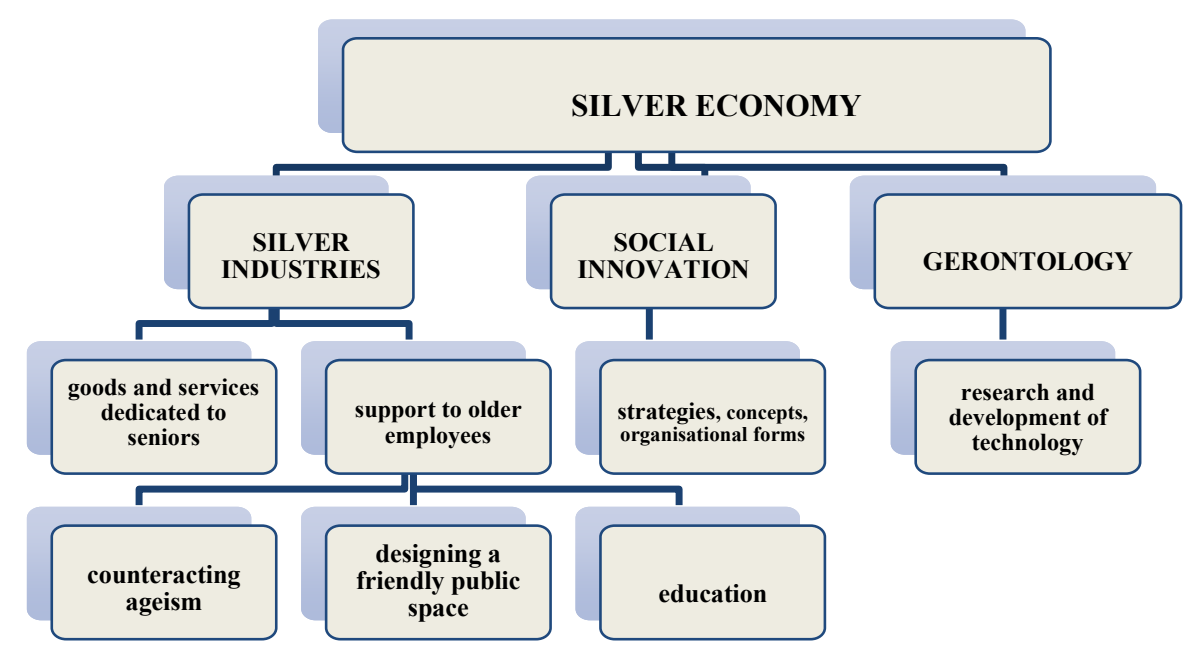

Fig. 2. Areas of silver economy activities.

The figure shows a multi-purpose area of silver economy implementation, comprising both products and services dedicated to the seniors and including such issues as: strengthening social cohesion, inclusion and social participation of the seniors, supporting and propagating their participation in the labour market, propagating seniors' activity and health and their independent life as well as research and innovation aiming at improvement of life of the elderly. Such approach to the areas of silver economy activities fully implements the assumptions indicated by the Council of the European Union [6].

The significance of silver economy development in rural areas is enormous since it demonstrates greater difficulties in the access to care services and social infrastructure which would facilitate functioning of seniors living there compared to urban areas. The current state of affairs is not satisfactory and the development of silver economy is the opportunity to reduce inequalities in the access, among others, to care services, to increase the multifunctional character of rural areas as well as to enhance broadly understood economic development.

The implementation of silver economy must also take into account the fact that the community of the elderly is not homogeneous. The seniors differ between each other in many ways - both due to features of social diversification characteristic for the society as a whole (economic status, social status, social and cultural capital held, gender, physical and mental condition) as well as differentiation due to age. The reason is that needs of persons $60+$ are different than those of $90+$ persons - more differences than similarities can be found among them. Thus, in order to respond in an adequate way to the seniors' needs and to achieve economic and social successes, heterogeneity of the senior community should be taken into account. Thus, the issue of building regional development strategies becomes essential, where direct activities targeted at and addressed to seniors will have a significant share. Therefore, in the development of 
silver economy in rural areas it is essential to focus attention on two development paths presented in Figure 3.

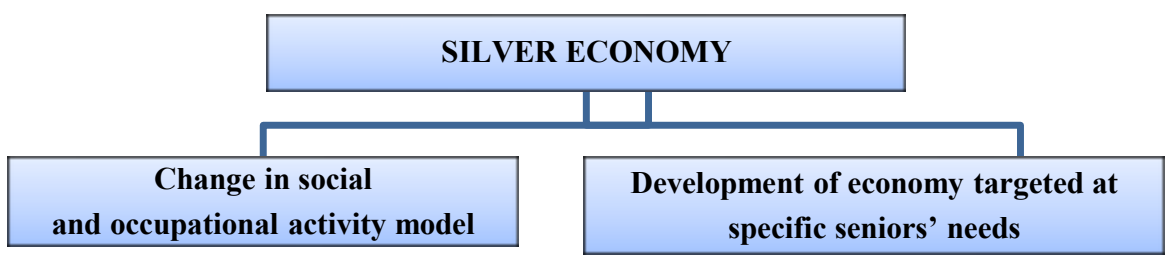

Fig. 3. Silver economy development paths in rural areas.

Outlining general directions of silver economy for the country, forming a part of the European Union assumptions in this area becomes important. Possibilities of implementation of the general assumptions should arise from the specific nature of the particular region, character of the municipality, they should be adjusted to local needs in the scope of support of various areas of seniors' functioning, they should also take into account financial capacity and resources of entities responsible for activities and participating in the implementation of projects.

\section{$4 \quad$ Silver Economy in Selected National Strategic Documents}

The policy related to ageing of societies refers to many areas of support, such as employment, equality of opportunities in the access to products and services, innovation, education or broadly understood care. Determining the priority directions of actions and the analysis of possibilities for their implementation and support is required in the case of silver economy, to which attention started to be paid and whose significance in the country started to be emphasised relatively recently. Elements required for its effective development include: coordination of various policies, cooperation between bottom-up and top-down initiatives, consistency of strategic documents, multi-level shared management, integration and reorganisation of public services towards the development and co-production of services with citizens or dialogue between local communities and administration [11]. In accordance with the classification of welfare state models proposed by Yuri Kazepov, Poland belongs to the model comprising the majority of countries of Central and Central-East Europe (undergoing system transformation) demonstrating social policy reform occurring under the conditions of financial limitations (generating ambivalent effects), and implementation of significant reforms of territorial administration oriented to decentralisation of social benefits and services - often triggering further deepening of regional and local differences [11]. Under such conditions, adequate programmes and strategies are required, in particular in the context of signalling and initiating measures necessary for the proper functioning of seniors in the future.

Strategic national strategic documents significant in terms of silver economy include: 
- Governmental Programme on Social Activity of the Elderly for the years 2014-2020 - aimed at improvement of the quality and level of life of the elderly for ageing based on dignity through social activity, taking into account the internal diversity of the elderly population [20],

- Assumptions of the Long-term Senior Policy in Poland for the years 2014-2020 constituting the specific set of necessary activities in the area of senior policy in Poland, addressed to a wide target group: the society, public authorities at all levels, private sector and NGOs as well as social partners [21],

- Solidarity of Generations Programme. Activities to increase occupational activity of persons aged 50+ - comprising a broad spectrum of initiatives aimed at better use of human resources of persons aged 50 and more [22],

- Long-term Development Strategy for the Country "Poland 2030. Third Wave of Modernity" - where the growth of social development capital was adopted as objective 11 and one of intervention directions focused on the preparation and introduction of the civic education programme at all levels of education, in the perspective of life-long learning [12],

- Human Capital Development Strategy - taking into account human capital building throughout the entire life cycle, including at the stage of occupational activity, adult learning and parenthood as well as old age [19],

- Multi annual Programme "Senior+" for the years 2015-2020 (in 2015-2016-Multi annual Programme "Senior - WIGOR") - the aim of which is to increase active participation of seniors through co-financing of local government entities in the development of a network of "Senior+" Day Centres and "Senior+" Clubs on their territory [17],

- Programme "Care 75+" for the years 2015-2020 - aimed at improvement of access to care services and specialised care services to lonely elderly persons aged 75 and more [14].

The majority of strategic documents contains proposals of measures addressed to and targeted at the seniors, treating this community as a whole or taking into consideration the internal diversification of this population, however, the differentiation of projects from the point of view of "seniors in cities" and "seniors in rural areas" can be hardly seen. Therefore, an attempt aimed at placement and assessment of the senior policy importance in examples of the programmes is undertaken below, taking into account the space of residence.

\section{$5 \quad$ Silver Economy in Selected Documents and National Programmes Addressed to Rural Areas}

One of the strategic documents taking into account the criterion of space is the National Regional Development Strategy 2010-2020. Regions, cities, rural areas. This Strategy takes into consideration the territorial diversification of potentials, including the social capital, identifying as its strategic objective the "effective use of regional and other territorial development potentials to achieve the aim of country development - growth, 
employment and cohesion in a long-term timeframe" [16]. Although measures addressed strictly to $50+$ persons are not taken into account in the document, nevertheless, the necessity of special treatment of those rural areas which have the worst access to public services determining development opportunities was indicated. Activities implementing the strategic objective of the National Regional Development Strategy, with positive impact on the development of rural areas included, among others, measures increasing transport availability, development of institutions of business environment, horizontal activities in the scope of human, intellectual and social capital. These measures indirectly determine functioning and development of the seniors in rural areas, affecting the shape of the labour market, availability of services and educational opportunities.

It seems that the programme which - due to its designation - should consider the needs of the ageing society of the Polish village to a largest extent is the Development Programme of Rural Areas for the years 2014-2020. Unfortunately, measures directly addressed to the 50+ target group can be hardly found in it - in fact, this group of beneficiaries can be seen in two specific objectives of the Programme: within Priority 1: Facilitating the transfer of knowledge and innovation in agriculture, forestry and in rural areas, objective 1C: Supporting long-life learning and vocational training in the agricultural and forestry sectors and within Priority 6: Promoting social inclusion, reduction of poverty and economic development in rural areas, objective 6B: Supporting local development in rural areas. The local development comprises, among others, the construction or modernisation of local roads, it means, the measure fostering undertaking employment outside the place of residence or use of public services comprising education, health or culture [13]. The vast majority of measures supported under the PROW comprises occupationally active farmers - obviously, persons aged $50+$ may also use other measures related to the growth of competitiveness, modernisation of farms, improvement of the quality of products, nevertheless - as Poland's experience in the implementation of the programme in previous programming periods shows - these projects are mainly implemented by younger agricultural producers. Undoubtedly, the Programme contains a limited number of measures addressed to inhabitants of the village other than farmers and to persons from higher age categories. This confirms the aforementioned fact of the relatively short interest in silver economy problems in Poland and the failure to take it into account in many currently valid documents.

Although the issue of life quality of the seniors in rural areas requires a greater involvement of various social groups, the problem is more and more commonly noticeable, similar to the progress in implementing various solutions. An example is a pilot Programme Active and Healthy Senior Farmer - a project launched by the Agricultural Social Insurance Fund (KRUS), the Farmer Social Insurance Contribution Fund and the Polish Public Health Association in April 2018. The Programme was created as a result of search for innovative solutions comprising the organisation and provision of care services, rehabilitation and health prophylaxis among farmers, taking into account the accident risk in agriculture, diseased typical for the older age and the specific character of the agricultural work [1]. Active and Healthy Senior Farmer assumes, among others, complex day care with elements of rehabilitation, complex 
stationary rehabilitation, short-term stays with accommodation for the elderly, combined with rehabilitation - within the support of caretakers of the elderly, e.g. in the period of intensified works on a farm [2]. The prerequisite for participation in the programme is holding the KRUS insurance.

One of the programmes addressed, among others, to seniors inhabiting rural areas is the aforementioned Multi annual Programme "Senior+" for the years 2015-2020. Its beneficiaries include local government units, including rural communes whereas the seniors represent the ultimate target group, with the financial support allocated for the improvement of their life quality. The outcomes of the implementation of the "Senior+" Programme in rural areas up to date are presented in Table 1.

As the table shows, the number of communes which used the opportunity to participate in the "Senior+" Programme is not impressive (over 2100 rural communes and rural-urban communes exist in Poland), especially that some entities which were granted the support in the first years of the Programme functioning for establishment of the Senior Day Care Centre or Senior Club, also applied in the subsequent years for the purpose of ensuring the functioning of those facilities (repeatability of beneficiaries).

Table 1. Support to rural communes (R) and urban-rural communes (U-R) under the Multi annual Programme "Senior+" The advantages of social farming [15].

\begin{tabular}{|c|c|c|c|}
\hline Module & $\begin{array}{l}\text { Number }(\mathrm{R}) \text { and }(\mathrm{U}-\mathrm{R}) / / \\
\text { percentage of the total } \\
\text { number of beneficiaries of } \\
\text { the module }\end{array}$ & $\begin{array}{l}\text { Number of } \\
\text { places in } \\
\text { facilities }\end{array}$ & $\begin{array}{c}\text { Amount of } \\
\text { subsidy (PLN) }\end{array}$ \\
\hline \multicolumn{4}{|c|}{ "Senior-WIGOR" Programme (2015-2016) } \\
\hline $\begin{array}{l}\text { "Senior-WIGOR" day } \\
\text { care centres } \\
\text { "Senior-WIGOR" clubs }\end{array}$ & $\begin{array}{c}\text { (R): } 30 / / 25.2 \% \\
\text { (U-R): } 41 / / 34.5 \%\end{array}$ & - & $\begin{array}{l}6,630,847.57 \\
9,186,658.13\end{array}$ \\
\hline \multicolumn{4}{|c|}{ “Senior-WIGOR” Programme (2017-2018) } \\
\hline $\begin{array}{l}\text { Establishing or } \\
\text { furnishing of the "Senior- } \\
\text { WIGOR" day care centre }\end{array}$ & $\begin{array}{c}\text { (R): } 38 / / 38.0 \% \\
\text { (U-R): } 28 / / 28.0 \%\end{array}$ & $\begin{array}{l}891 \\
612\end{array}$ & $\begin{array}{l}8,813,625.26 \\
6,453,653.03\end{array}$ \\
\hline $\begin{array}{l}\text { Establishing or } \\
\text { furnishing } \\
\text { of the "Senior+" club }\end{array}$ & $\begin{array}{l}\text { (R): } 126 / / 54.8 \% \\
\text { (U-R): } 51 / / 22.2 \%\end{array}$ & $\begin{array}{l}2951 \\
1297\end{array}$ & $\begin{array}{r}15,293,372.19 \\
5,748,351.25\end{array}$ \\
\hline $\begin{array}{l}\text { Provision of functioning } \\
\text { of "Senior+" - Day Care } \\
\text { Centre facilities }\end{array}$ & $\begin{array}{c}\text { (R): } 45 / / 28.9 \% \\
\text { (U-R): } 55 / / 35.3 \%\end{array}$ & $\begin{array}{c}891 \\
1264\end{array}$ & $\begin{array}{l}2,829,416.05 \\
3,952,134.99\end{array}$ \\
\hline $\begin{array}{l}\text { Provision of functioning } \\
\text { of "Senior+" }- \text { Senior } \\
\text { Club facilities }\end{array}$ & $\begin{array}{l}\text { (R): } 31 / / 41.3 \% \\
\text { (U-R): } 28 / / 37.3\end{array}$ & $\begin{array}{l}610 \\
770\end{array}$ & $\begin{array}{l}804,304.83 \\
806,538.63\end{array}$ \\
\hline
\end{tabular}

* Lack of data across the modules and information concerning the number of places in the facilities.

So far, rural communes showed the greatest interest in the possibility to establish or equip a "Senior+" Club, the activity of which involves motivating the seniors to 
undertake self-aid and voluntary activities (over a half of the overall number of beneficiaries of this Programme module).

\section{Conclusion}

In face of the current demographic tendencies, the implementation of silver economy assumptions seems necessary. The earlier the potential of the seniors is recognised, the greater development benefits may the national or regional economy gain. It seems that currently in Poland progress has been achieved in operationalisation of activities in the area of silver economy at quite a general level - programmes addressed to seniors as the overall community are created. However, roadmaps are missing for the implementation of senior policy for specific segments of elderly populations distinguished due to, for example, their place of residence, age groups, level of wealth, health condition. An example may the group of seniors inhabiting rural areas which has so far been hardly addressed in strategic documents and programmes, which is in a more difficult situation in many respects (e.g. access to specific goods and services) than inhabitants of cities. Much more attention should be definitely paid to seniors in rural areas, which is determined by the contemporary image of the Polish village - the senior care model based on the multi-generation family is not as popular as before and agricultural population does not prevail in each village.

As results from the conducted research, the silver economy is implemented in rural areas mainly through the inclusion and social participation of seniors and strengthening social cohesion, in which areas the Senior Club plays a major role. Little progress has been observed so far in promoting seniors' activity and health, or promoting their participation in the labor market. It is also difficult to break up in the Polish countryside with the tradition of staying only in their own environment, which limit access to many goods and services dedicated to seniors, but offered at regional rather than local level. Therefore, it is necessary to reach out to residents of rural areas aged 50 who with their senioral products and services which make a huge market for them.

Participation in programmes enabling to acquire support for the implementation of tasks related to senior care is usually voluntary, therefore, it requires mainly the awareness of the usefulness of activities of this type. Rural communes should perceive the necessity to join various pro-senior programmes - although still not numerous, however, functioning - due to the fact that the unfavourable demographic situation is particularly visible in small communes where the process of society ageing proceeds at a much faster pace than across the country, and difficulties in providing care services are particularly visible.

\section{References}

1. Active and Healthy Senior Farmer - the conference launching the pilot KRUS Programme, Warsaw, 2018, https://www.krus.gov.pl/aktualnosci/dokument/ar tykul/aktywny-i-zdrowy-senior-rolnik-konferencja-inaugurujaca-pilotazowy-programkrus/, last accessed 2018/08/16. 
2. Active and Healthy Senior Farmer, http://ksow.pl/news/entry/13209-aktywny-i-zdrowysenior-rolnik.html, last accessed 2018/08/16.

3. Central Statistical Office: Population forecast for 2014-2050. Warsaw (2014).

4. Commission of the European Communities: Dealing with the impact of an ageing population in the EU (2009 Ageing Report) (COM(2009 180 final). EU COM, Brussels (2009).

5. Commission of the European Communities: The Demographic Future of Europe - from Challenge to Opportunity (COM(2006) 571 final). EU COM, Brussels (2006).

6. Council Declaration on the European Year for Active Ageing and Solidarity between Generations, Brussels, 7 December 2012, 17468/12, http://register.consilium.europa.eu/do c/srv?1=PL\&f=ST\%2017468\%202012\%20INIT, last accessed 2018/03/14.

7. Enste, P., Naegele, G., Leve, V.: The Discovery and Development of the Silver Market in Germany. In: Kohlbacher, F., Herstatt, C. (eds.) The Silver Market Phenomenon. Business Opportunities in an Era of Demographic Change, pp. 330-331. Springer, Heidelberg. (2008).

8. European Commission: The 2015 Ageing Report: Economic and budgetary projections for the EU 28 Member States (2013-2060). European Economy, no 3, pp. 1-424. Luxembourg (2015).

9. Golinowska, S.: Silver economy - an element of regional development strategy. Małopolskie Studia Regionalne, no 2-3, pp. 31-32. The Marshal's Office of the Małopolska Region, Kraków (2014).

10. Iwański, R.: Long-term care after the elderly. CeDeWu.pl., Warsaw (2016).

11. Klimczuk, A.: "Silver economy" models in the European Union in comparative terms: an attempt to introduce the discussion. Problemy Zarządzania, no 14/2 (1), pp. 41-59. University of Warsaw, Warsaw (2016).

12. Ministry of Administration and Digitisation: Poland 2030. Wave of Modernity. Longterm Development Strategy for the Country. Warsaw, 11 January 2013, http://www.kigeit. org.pl/FTP/PRCIP/Literatura/002_Strategia_DSRK_PL2030_RM.pdf, last accessed 2018/08/16.

13. Ministry of Agriculture and Rural Development: Development Programme of Rural Areas for the years 2014-2020, Warsaw, 2014, https://www.gov.pl/rolnictwo/-program-rozwojuobszarow-wiejskich-2014-2020-prow-2014-2020, last accessed 2018/08/16.

14. Ministry of Family, Labour and Social Policy: Programme "Care 75+" 2018 (amendment), Warsaw, https://www.mpips.gov.pl/seniorzyaktywne-starzenie/program-opieka-75/, last accessed 2018/08/21

15. Ministry of Family, Labour and Social Policy: Results of open competitions for offers under the Multi annual Programme "Senior+" for the years 2015-2020. Issue 2015-2018, https://www.mpips.gov.pl/seniorzyaktywne-starzenie/program-senior/, last accessed 2018/08/21.

16. Ministry of Regional Development: National Strategy of Regional Development 2010-2020. Regions - cities - rural areas. Warsaw (2010).

17. Multi annual Programme "Senior+", Annex to Regulation No 157 of the Council of Ministers of 20 December 2016 (item 1254), https://www.mpips.gov.p1/seniorzyaktywnestarzenie/program-senior/program-senior-/, last accessed 2018/08/21.

18. OECD: University of Oxford, Global Coalition for Ageing, The Silver Economy as a Pathway for Growth. Insights from the OECD-GCOA Expert Consultation, 26 June 2014, https://www.oecd.org/sti/the-silver-economy-as-a-pathway-to-growth.pdf, last accessed 2018/07/10

19. Resolution No 104 of the Council of Ministers of 18 June 2013 concerning the adoption of the Human Capital Development Strategy 2020, Monitor Polski, Warsaw, 7 August 2013, item 640 . 
20. Resolution No 237 of the Council of Ministers of 24 December 2013 concerning establishing of the Governmental Programme on Social Activity of the Elderly for the years 2014-2020, Monitor Polski, Warsaw, 24 January 2014, item 52.

21. Resolution No 238 of the Council of Ministers of 24 December 2013 concerning adoption of the document: Assumptions of the Long-term Senior Policy in Poland for the years 20142020, Monitor Polski, Warsaw, 4 February 2014, item 118.

22. Resolution No 239 of the Council of Ministers concerning establishing of the Solidarity of Generations Programme. Activities to increase occupational activity of persons aged 50+, Monitor Polski, Warsaw, 4 February 2014, item 115. 